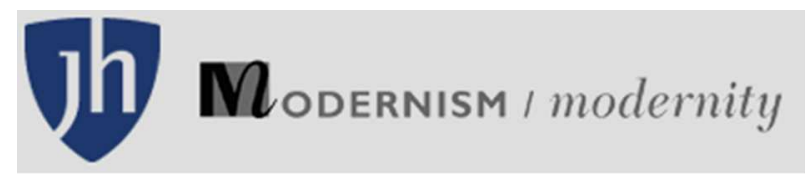

\title{
Ink Splashes on Camera: Calligraphy, Action Painting, and Mass Media in Postwar Japan
}

\begin{tabular}{|r|l|}
\hline Journal: & Modernism/modernity \\
\hline Manuscript ID & Draft \\
\hline Manuscript Type: & Original Manuscripts \\
\hline Keywords: & $\begin{array}{l}\text { calligraphy, postwar Japan, Japanese art, action painting, abstract art, } \\
\text { modernization, performativity, mass media, art journalism }\end{array}$ \\
\hline \multicolumn{2}{|l}{} \\
\hline
\end{tabular}

\section{SCHOLARONE ${ }^{m}$ \\ Manuscripts}




\section{Ink Splashes on Camera: Calligraphy, Action Painting, and Mass Media in Postwar Japan}

The rapid postwar modernization and internationalization of Japanese calligraphy coincided with the global spread of action painting. But scholarly discussions of action painting, even those that employ transcultural and comparative approaches, have for the most part failed to see the connection. ${ }^{1}$ Calligraphy is mentioned as a source of inspiration for postwar abstract painters, and the works of Pollock and Mathieu have occasionally been compared to East Asian calligraphy. ${ }^{2}$ Indeed, on his trip to Japan in 1957, Georges Mathieu publicly acknowledged that he had been inspired by the wild cursive calligraphy of ancient China, and Pollock's method of laying his canvases on the floor has been thought to resemble calligraphic practice. ${ }^{3}$ But, tangled as it is, the nexus between Japanese calligraphy and action painting demands attention. In particular, the role that the calligraphers themselves, who were engaged in the strategic internationalization of their practices, played in this exchange has yet to be explored.

Calligraphy was perhaps the last of Japan's art forms to undergo modernization. By the early twentieth century, the calligraphers, who had ardently resisted the new artistic and cultural system imposed by the Meiji reforms of the preceding century, found themselves excluded from the official, state-sponsored art institutions and organizations. In contrast to the privileged position that their traditional art form had held in the premodern period, its practitioners now were cut off from state-sponsored opportunities for dialogue and collaboration with other artists. In the 1930s the calligraphers had made a few feeble attempts to modernize their art for viewers, but it was only during the post-war period - with its near-total transformation of Japanese political, social, and cultural life - that calligraphy achieved new status as a highly visible form of modern art. 
Paradoxically, the calligraphers' new visibility after the war was triggered by yet another act of exclusion. In 1946, the Allied occupation forces—in particular the U.S. Education Mission to Japan, which questioned the usefulness of calligraphy for the age of print media, radio, and television - had ousted calligraphy from the educational curriculum, which had been the calligraphers' only refuge in an official Meiji cultural system that had otherwise excluded them. The shock of this final institutional uprooting pushed the calligraphers to take a proactive stance and start a dialogue with a wide range of cultural players in a struggle for the survival of their art. $^{4}$ At this watershed moment, a group of young Japanese calligraphers broke with tradition in an effort to prove the relevance of their art to new audiences. In its epistolary manifesto, the Bokujinkai group, which formed in Kyoto in 1952, declared:

Now, a great future is opening in front of calligraphy. European and American avant-garde artists, and Japanese progressive artists and art critics, keep knocking on calligraphy's doors.... The world of calligraphy, which has long been hibernating in the shell of authoritarianism, is finally being shaken from outside. Calligraphic art, which has preserved a long tradition in a remote corner of the Orient, has finally come into sight of the world. But will it be able to resurrect itself as a truly modern art, or will it be abandoned and self-destruct after progressive artists have absorbed its essence? We acutely feel that we are standing at this crossroads right now. When we think about it, we feel like we cannot lose even one day. ${ }^{5}$

With these words, the postwar generation of Japanese calligraphers launched the ambitious and perilous venture of reshaping calligraphy's public image as a modern art form, and the new calligraphy—known as both avant-garde zen'ei and modernist kindai—was born. 
For the Japanese calligraphers who were pursuing this agenda of radical modernization during the late '40s and early '50s, international abstract art was a central point of reference for the "modern," and the calligraphic sections of European Informel and American Abstract Expressionism offered access to broader international visibility. But it was the perceived analogy between calligraphy and the new action painting — facilitated in large part by the media — that would catapult the calligraphers into the public eye. In turn, the calligraphers, engaged in the strategic internationalization of their practices, would persistently share their new performative theories and practices with action painters worldwide.

\section{The View from TV Journalism: Bundō Shunkai and Calligraphy as Spectacle \\ On January 5, 1952 visitors of the Tokyo Metropolitan Museum witnessed a large-scale calligraphy performance by one of the most influential but also most traditional calligraphers of the modern era, a Tendai Buddhist monk Bundō Shunkai (1878-1970).}

Head of both the Zuiun (Auspicious Cloud) calligraphy group and the selection committee for the calligraphy section of the yearly government-run Nitten art salon, Bundō acknowledged the Tokyo Metropolitan Museum for their support of calligraphy by staging a calligraphy demonstration at the annual commemoration of the museum's founding. An impressive strip of paper about 36 meters long and 6 meters wide was spread on the floor of the exhibition hall. Surrounded by the crowd of the viewers, Bundō performed his art, stepping on the paper as if dancing, with the audience breathlessly following each of his movements.

Entering the vast white space amidst the surging crowd, the calligrapher stood for a moment in 
the center of his future artwork (plate 1). An old man of seventy five, with a long white beard and a monk's black attire, Bundō's slight figure appeared solemn and solitary, as if dwarfed by the sea of paper. After a moment of contemplation, the action starts. Taking up a brush so big that it resembled a broom for sweeping streets, the calligrapher dipped it into a large bucket of liquid ink. At this point his body becomes tense, the inked brush being very heavy. He moves with extreme focus, since there will be no chance for correction under the gaze of hundreds of eyesas well as extremely fast, since this is the only way to keep the writing integrated and maintain the natural flow of the brushstrokes. As Bundō Shunkai writes, he steps backwards. Occasionally, assistants enter the paper arena to supply new ink for the master's brush or straighten folds of paper. Several photo journalists run along the margins of the paper sheet, attempting to follow Bundo's rapid movements as his painting evolves and trying to capture every aspect of his unusual action, from various angles and at different stages. As the calligrapher approaches the end of the white sheet, four huge characters are left behind, as if to mark his passage (plate 2). Now the audience can read an ancient Chinese proverb: 龍翔鳳舞 ryūshō hōbu ("Rise into the skies like a dragon and dance like a phoenix").

Inscribed in early January, this was Bundō's kakizome - his first programmatic calligraphy of the year-announcing his wishes for the new year 1952. This auspicious and energetic motto introduced a year in which Japan would gain its independence from the Allied government, and expressed Bundō's hopes for a bright future, for his country as well as for calligraphy. To draw these characters Bundō had used the fast gyōsho (running) script, which corresponded both to the dynamism of the proverb's content and to the fast mode of his calligraphy performance. But given the scale of the artwork, it was neither the content of the kakizome, nor the style of the calligraphy, but the spectacle itself that attracted the most attention. The enormous size of the 
characters and the energetic gestures of Bundō as he danced with his huge brush lived on in the collective memory, fixed by the flashes of numerous cameras.

In their coverage of this show, the photographers focused on close-ups of the artist's movements. They also sought to capture the general atmosphere in the exhibition room by spotlighting the relationship between calligrapher, artwork, and audience through shots of Bundō's figure taken over the viewers' heads, or images of him spreading ink on paper at the viewers' feet or moving in the white paper field surrounded by a dense ring of onlookers. Remarkably, not a single shot of the finished calligraphy was taken. The next day, a photograph of this performance appeared in Japan's leading newspaper, Yomiuri-a rare honor for calligraphy-related events (plate 3). The photograph was accompanied by a detailed description of the scale of the calligraphy and the observation that the artist had "received a great ovation from the viewers."

Such close attention to Bundō Shunkai's calligraphy from the Yomiuri was not accidental. The year before, in 1951, Yomiuri had organized the Third Yomiuri Independent Exhibition at the same venue, Tokyo Metropolitan Art Museum, which showed works of the new generation of abstract painters, including Jackson Pollock, for the first time in Japan. ${ }^{7}$ Photographs of Pollock's works, as well as Hans Namuth's famous photographs of Pollock at work, which transformed the perception of modern art in the United States, ${ }^{8}$ circulated among Japanese art professionals too, discussed in various art groups and reviewed by the most prominent Japanese art critics. ${ }^{9}$ The film of Pollock's performance also screened in Japan in early 1952. Namuth's photographs and film of Pollock painting encouraged Japanese art correspondents and critics to look for such performativity in Japanese art, and calligraphy turned out to be a fertile ground for this pursuit, as Yomiuri's art reporters pointed out. By focusing on Bundō's close relationship with the paper, his skill at wielding the dripping ink, and the excited gaze of the viewers 
following his movements, the reporters offered a new perspective on Japanese calligraphy that compared it to the latest international art trends. Since Bundō was on the conservative side of the calligraphic scene, it is inconceivable that he himself would have drawn such an analogy between himself and Pollock, or that he would even have tolerated such comparisons; yet his performance reminded audiences that large-scale calligraphic performances had for a long time been a constituent part of the Japanese art practice, and inspired them to think about calligraphy in terms of speed, expressivity, spectacle, and spontaneity—features it shared with action painting.

As Japanese audiences (unlike European and American audiences) were well aware, exalted selfexpression in calligraphy had long been celebrated in the Chinese tradition of kuangcao ("wild cursive") script, which emphasized movement through time and space as well as extreme individual expressivity. Legend has it that Zhang Shu, one of the most prominent calligraphers of the Tang Dynasty, created calligraphy when drunk and, following his creative impulse, wrote calligraphy on the blank walls using his hair-soaked in ink - as a brush. ${ }^{10}$ Although none of the Japanese calligraphers could actually see these legendary but non-extant works of the ancient Chinese masters, anecdotes about them circulated widely among both calligraphers and the general public, and its artists' eccentricities came to be regarded as a distinct mode of calligraphic practice. Dynamic calligraphic performances such as those of Bundō Shunkai and Nantenbō Tōjū before him were inevitably associated with the tradition of kuangcao and perceived as such by viewers. ${ }^{11}$

Yet perhaps the most noteworthy aspect of Bundō's performance, in terms of its public resonance, was the fact that Japanese television covered it in one of its first broadcasts, in 1952. This was the era before regular television programming, when broadcasting was still irregular 
and offered only a few hours per day, and Bundō's large-scale performance was one of the first events shown. The spectacular scale of the performance, the prominent venue, the distinguished attendees, the numerous interested viewers, and the auspicious nature of kakizome - all of this brought Bundō's calligraphy to the vanguard of Japanese visual culture, creating a close association between Japanese traditional art and the rapidly developing new technology—a connection much desired in the postwar era. Curiously, the news program broadcast photographs of Bundō's performance rather than a moving image of him writing, no doubt due to technical limitations. ${ }^{12}$ Nevertheless, it was the performative aspect of his calligraphy that had an impact on viewers.

In the dynamic setting of postwar Tokyo, the performance by Bundō Shunkai exposed a deepseated tension between past, present, and future — in this case, the complex relationship between traditional art forms, contemporary art, and rapidly developing technology — that was not only central to calligraphy as an art form, but critical for the postwar era in Japan in general.

\section{The View from the International Artist as Filmmaker: Calligraphy as Dynamic Flow}

A new way of integrating Japanese calligraphy into international performative endeavors was soon offered by a Belgian abstract painter associated with the COBRA group, Pierre Alechinsky (b. 1927). In 1955 Alechinsky came to Japan on a fellowship from the Belgian government to explore the creative potential of Japanese calligraphy from the viewpoint of a European abstract artist. His research resulted in several articles in French, English, and Japanese; a 16-minute art documentary, Calligraphie Japonaise, and a lifelong exchange with Japanese calligraphers. ${ }^{13}$

The idea of making a film to document current developments in contemporary Japanese 
calligraphy occurred to Alechinsky when he was first exposed to the creative calligraphic scene of Kyoto. Originally interested in the surrealist approach to script and semiotics, Alechinsky found himself in an environment where visually appealing yet (for him) illegible script created an artistic and cognitive overstimulation that was both aesthetically overwhelming and irresistibly alluring. Indiscriminately showing street signs, shop curtains with inscriptions, newspapers, handwritten letters, advertisements, and stone engravings, Alechinsky observes in his film that "The streets are filled with images. On signs, flags, objects from daily life, language decorates the city." ${ }^{\prime 14}$ Walking through the streets of Kyoto, which were covered with scriptancient yet contemporary, real yet inaccessible, pictographic yet abstract—feels to Alechinsky like sleepwalking in the surrealist dream of an abstract language. The rhythmic poetic narration and surrealist music of the film enhance this impression and create a uniquely artistic rather than documentary space for Calligraphie Japonaise.

In the film, after overloading viewers with a critical mass of written script, Alechinsky attempts to help them find a way through it. He selects as his path the cognitive and physical experience of writing, rather than the script itself. Showing a small boy scribbling with a stick in the sand, Alechinsky theorizes that "the joy of drawing characters was born in the sand, even before school and paper existed. It's older than art and history."15 From there he moves on to show older children, first playing in a school yard, then learning characters and practicing calligraphy in a classroom (plate 4). The children repeat with their hands the movements of their teacher, who demonstrates character strokes in the air - a standard practice for learning characters that, seen through Alechinsky's eyes, looks almost like a devotional ritual—as if imparting a transcendental quality to the script. He comments that "children can learn determination and ability in their gestures. .. . The child restrains itself, with controlled breaths, and conquers the 
characters that will fill its mind." ${ }^{, 16}$ For Alechinsky, this suggests that Japanese culture values script not only as a visual, but also as a physical and metaphysical experience.

Alechinsky suggests a link between this transcendent style of learning and the Zen practice of using calligraphy in meditation in the next scene, which shows a Zen monk practicing calligraphy in a temple, "forgetting himself and the outside world in the process." ${ }^{17}$ As Alechinsky points out, in Zen, the physicality of the act of writing gains a meaning independent of the semantics of the written language. The very process of writing - its technique, speed, setting, and flow—acquires a creative potential of its own, emancipated from its semantic content or even cultural context. Alechinsky's only reservation regarding the Zen view of calligraphy is its rootedness in rigid training and its compliance with the strict hierarchies of the community of calligraphers, which make it inaccessible to someone like himself. In response, he enthusiastically presents young avant-garde calligraphers who aim to transcend the limitations not only of the conventional calligraphic societies but of traditional methods. As he points out, for the avant-gardists "it took courage to cast off education and to revolt against the seemingly rigid order." ${ }^{18}$

Alechinsky focuses on the unique ways four avant-garde calligraphers-Eguchi Sōgen, Morita Shiryū, Shinoda Tōkō, and Ōsawa Gakyū—searched for new forms of calligraphic practice. Two of the calligraphers he selects, Morita Shiryū and Eguchi Sōgen, belonged to the famous avant-garde calligraphy group Bokujinkai ("People of the Ink"), which by coincidence was founded in Kyoto on January 1952, the day of Bundō Shunkai's performance at Tokyo Metropolitan Museum. Dedicated to bringing Japanese calligraphy to an international level, these artists struggled to make the art form more accessible for international viewers, who could 
not read characters. To this end they reached out to and collaborated with foreign abstract painters in joint exhibitions, publications, and theoretical discussions. Alechinsky himself became aware of Japanese avant-garde calligraphy through the journal Bokubi (Beauty of Ink), edited by Morita Shiryū, which he saw at William Hayter's studio. This resulted in a yearlong correspondence between Morita and Alechinsky and the regular exchange of art journals - the Bokubi, edited by Morita, and CoBrA, edited by Alechinsky. ${ }^{19}$

In Calligraphie Japonaise Alechinsky depicts Morita primarily as an avant-garde artist rather than as a theoretician or scholar. He shows Morita working barefoot in his atelier, dressed in wide trousers rolled up to his ankles and a short-sleeved t-shirt. Alechinsky follows him as he prepares ink in a deep bowl, pours it into a basin, picks up a large bundle of half-a-dozen smaller brushes tied together, stops for a second in front of a large sheet of paper spread on the floor, lifts the inked brush along with a piece of newspaper to catch the droplets, and finally steps on the paper (plate 5). At this moment, the action starts. Morita attacks the paper in front of him, jumping with his feet to make space for the brush and moving his head in rhythm with the brush, as if the brush were taking the lead. He stops for a second in contemplation-Alechinsky highlights this moment with a theatrical close-up of Morita's concentrated face- - before dramatically applying his final stroke. In Alechinsky's view, Morita "falls back on the elementary power of ink. To create, he abandons all examples, and amidst the chaos his movements are cast out like screams. ${ }^{20}$ The expressive musical score, closely aligned with Morita's movements, renders this action even more dynamic and forceful. In the film, it takes Morita only sixteen seconds to complete his work, riding the momentum of his creative impulse. Impressed by this technique, Alechinsky's two largest artistic take-aways from Japan were just that: the technique of placing paper on the floor to enter into a different relationship with it and 
the importance of speed in creating one's work.

In the final scene of the film, Alechinsky concludes that "A calligrapher is free in his movements, and animates the characters.... The characters leave the written pages. Transcending different educations, the universal language of art is formed." ${ }^{21}$ At this point a flock of birds flies across a clear sky—like characters that have taken off from written pages—as if to declare calligraphy free from any limitations and announce a new era of interaction between artists across the globe based on a universal language of movement, gesture, and artistic impulse.

It is noteworthy that Pierre Alechinsky, primarily an abstract painter and printmaker, was not originally a filmmaker; it was his encounter with the practices of contemporary Japanese calligraphers that made him reach out to this medium. In fact, while Alechinsky was the first to conceive of the documentary, he relied for its realization on a constellation of international, mostly European, film professionals and photographers. These included Tokyo-based Hungarian photographer Francis Haar, Belgian painter and poet Christian Dotremont, and Belgian surrealist composer André Souris, among others. Thus, while Alechinsky's paintings drew inspiration from calligraphy, he consciously selected film as the medium most suitable for capturing the movements and temporal dimension of calligraphy. The collaborators' efforts were rewarded, and the film won an international prize at the Bergamo Film Festival in 1957. Alechinsky's Calligraphie Japonaise affected European and American abstractionists by introducing them to the dynamic and rapidly evolving art of contemporary Japanese calligraphy. But it also made the Japanese calligraphers involved in production of the film—-most importantly Morita and Eguchi, two key figures of the new avant-garde movement — see their own art with new eyes as a dynamic performative action with international reach. 


\section{The View from the Manga Artists: The Calligrapher Next Door}

By this point, the idea of avant-garde calligraphy and its spectacular but also puzzling performative quality had entered the larger visual field of postwar Japan, and soon reached the mass media. One of the most popular postwar newspaper manga series, Sazae-san by Hasegawa Machiko, featured an episode dedicated to avant-garde calligraphy in Japan's leading Asahi newspaper on January 31, 1956. Since the readership for the morning edition of this manga series was close to seven million, the number of people who saw the episode on avant-garde calligraphy was overwhelmingly large compared to the small size of the avant-garde calligraphy community itself. The Sazae-san series was itself a cultural phenomenon: a manga focused on the life of a young woman, Sazae Isono, who sees the post-war transformation of her country through her everyday experiences and family life. ${ }^{22}$ The series conveyed the atmosphere of postwar Tokyo by addressing phenomena encountered daily by its readers — from postwar hunger to the American presence in the city, women's rights, new technology, and the clash between traditional and modern culture. The sketchy, unpretentious, ironical episodes were filled with the charm of Sazae's witty conversation with her neighbors, making the Sazae-san series both a commercial success and a precise social record of the postwar era.

In the spirit of the rest of the manga series, the avant-garde calligraphy episode had a casual and ironical tone and showed a trivial interaction between two neighbors (plate 6). As a yonkoma or four-panel manga, this episode consisted of four consecutive scenes arranged vertically. The first panel, which introduced the topic of the episode, focused on a middle-aged man with a long moustache practicing avant-garde calligraphy, presumably at home. Dressed in casual Japanese 
housewear, barefoot, with short trousers, rolled-up sleeves, and a band over his head, the man is pulling a huge brush over the sheet of paper that he stands on. His legs are slightly bent, his feet placed widely apart, and his raised arms grip a large brush. The man's stiff, straight back and the sweat pouring down his face suggest that he is in a highly concentrated and exalted state of mind. The ink brushstrokes that surround his feet do not resemble any character or calligraphy. Comically drawn, the figure of the calligrapher resembles a sportsman, a martial arts practitioner, or perhaps someone doing his daily exercise routine at home. The next panel shows the calligrapher pausing, interrupted by someone calling him from outside. In the third panel another middle-aged old man, also with moustache and bald head, comes over to the calligrapher's porch with a letter in his hand. The neighbor explains that the mail carrier has mistakenly thrown a letter addressed to the calligrapher into his postbox. The neighbor is also casually dressed, although in more contemporary European attire: trousers, a vest, a fully buttoned shirt, and geta shoes with socks. In one hand he holds the letter and in the other he holds a large broom, as if he had been cleaning his porch or garden when the letter arrived. In the final scene, the visitor waves goodbye, apologizing to the calligrapher for having disturbed him while he was cleaning the house. It never occurs to the neighbor that the calligrapher might have been practicing the new avant-garde calligraphy with his huge brush and casual attire; he assumes he was simply sweeping the floor. The calligrapher is left standing on his porch in astonishment.

Like the Sazae-san manga series in general, this episode depicts a curious side of postwar Japanese life — the new calligraphy—with gentle irony and a cozy neighborly feeling. Hasegawa Michiko depicts avant-garde calligraphers as eccentrics who live next door and do something spectacular yet incomprehensible in their free time. The artist does not pass judgement on the quality of their calligraphy or its cultural value, but simply offers a humorous observation about 
how strange their art practice looks to the outsiders. This can be interpreted as an ironic comment on new postwar art movements in general or on the clash between the new calligraphy and what was commonly thought of as calligraphy. Hasegawa Michiko, with her sense for the zeitgeist, had already accepted avant-garde calligraphy as a part of the new Japanese reality, and her manga also presents the writing process — not the final abstract works — as the hallmark feature of this new art.

\section{The View from Photo Journalism: Inoue Yūichi and Calligraphy as a Battleground}

Five days later, as if to illustrate the point of view expressed in Hasegawa Machiko's manga, Asahi published another image of avant-garde calligraphy, this time a photograph by Sugano Yoshikatsu of a Bokujinkai calligrapher, Inoue Yūichi (plate 7). This image, which depicts Inoue in his atelier making calligraphy for the traveling exhibition "Contemporary Japanese Calligraphy" in Europe, is one of the most famous records of the performative and expressive aspect of postwar avant-garde calligraphy. ${ }^{23}$ At the time the photograph was taken, in 1955, Inoue's works had become abstract and entirely detached from language, the characters being treated as purely visual and not verbal. Furthermore, like Pollock, Inoue was using enamel instead of traditional ink, thus further challenging calligraphy’s conventions. ${ }^{24}$

This image, taken by Asahi's photographer Sugano Yoshikatsu, was prominently featured on the opening page of the special issue of Shükan Asahi dedicated to avant-garde calligraphy. Sugano, who was not specifically an art journalist, focused on calligraphy's performative aspect as the one that could potentially appeal to the widest readership. Sugano's specialization was not actually art, but social and political topics. During the Pacific War, he had produced propaganda, 
as had many other journalists; after the war he was most successful when covering acute political issues. His image of Tokyo's May Day demonstrations of 1952 was seen around the world and was republished in Life magazine. Skilled at capturing social trends, he used his ability to guess the mood and expectations of the public to create an innovative depiction of Japanese calligraphy in a dynamic image of high complexity and intensity.

Sugano's photograph of Inoue depicts the calligrapher, bare-chested, bent over a large sheet of paper, with elbows and feet smeared in thick black enamel. His face expresses the highest tension as he drives his heavy brush across the surface in front of him. His bodily position and the tense muscles on the arms express an almost painful physical and mental straining. Yüichi is absorbed by his activity, by the struggle between the brush and himself, and by the act of releasing his innermost emotions and ideas. He seems to become one with his work: on the one hand, the calligraphy leaves marks on his skin and clothes; on the other, he shapes the ink according to his will, leaving traces of his arms and feet on the paper as he touches and steps on it. The scene resembles a battle between two opponents, one animate and one inanimate, or the act of taming a wild spirit. The image is far from the conventional image of calligraphy as the peaceful leisure activity of educated idle men, and closer to the wild cursive tradition of classical China or to contemporary experimental art (including action painting) that explores the expressive abilities of motion and the proactive dynamic energy in art making. The inner state of the artist during the process of such intense creative action is memorialized in an entry from Inoue Yūichi's diary at the time this photograph was taken:

June 8: It is horrible. I made several large works and all of them are hopeless. Sweat flows into my eyes, and I can't see. The back of my legs is all smudged with enamel. When I walk, newspaper sheets stick to them firmly. Enamel is being used 
up very quickly, paper as well. Enamel runs on the hands. I put paper right on top of this chaos, step with my dirty feet on this paper, and absent-mindedly mess it up even more. [...] Sweat is in my eyes and I don't see anything. I can't control this chaos. Metallic sound of jazz. Dynamism. I have to reach the inorganic in man. Shit. Need to deny Hasegawa Saburō. What is calligraphy? Need to throw away and ignore all philosophies. Definitely have to read Hanada Kiyoteru. There are things that echo with Okamoto Tarō. Shall I write with coal tar? Zinc. Iron sheet. Wood. Stone or brick. I have to devote everything to the exhibition in Europe. Have to use up all enamel and paper. ${ }^{25}$

The author's inner state of confusion is mirrored in his works; the struggle with oneself turns out to be a struggle with the picture plane. The fact that Inoue Yüichi was photographed in such a tense, confused, and (to judge from the diary) uncomfortable state, suggests that the photograph is an intrusion into the artist's intimate space that depicts him doing something highly personal and emotionally exhausting. However, it was this image of the half-naked calligrapher stretched in an acrobatic movement, smeared in black paint and with a strange facial expression, that attracted the attention of the wider public, more than the works of abstract calligraphy themselves. Photographs of Jackson Pollock making his "drippings" were also at least as famous, if not more so, than his works. It is likely that Sugano had seen Namuth's images of Pollock painting when he was preparing for his work with Inoue, given that Sugano's newspaper, Asahi, had introduced Pollock to the public in 1951.

This method of representing contemporary calligraphers soon became an established visual mode of its own. The most celebrated postwar Japanese photographer, Dōmon Ken, applied the same approach in 1967 when he portrayed print artist Munakata Shikō in a way similar to Sugano's 
portrayal of Inoue (plate 8). Both images show half-naked artists secluded in their studios, immersed in painful and all-absorbing artistic creation, unaware of the outside world with its observers, and represented as mad, solitary geniuses bringing Japanese art—and calligraphy— to the vanguard of contemporary art. The authority of Dōmon Ken amplified and reinforced this way of representing avant-garde calligraphy.

This mode of visual representation so quickly overtook the popular perception of avant-garde calligraphy that less than a month after Sugano's photograph in Asahi, another manga series, Mappira-kun in the Mainichi newspaper, also featured an episode dedicated to avant-garde calligraphy (plate 9). Much like Sazae-san in Asahi, this manga also ironically depicted the messiness of avant-garde calligraphy through a humorous scene in which two Japanese men, one of them a calligrapher, interact, as if to make a joke about the dirty appearances of calligraphers engaged in avant-garde practices. When a taxi flings mud at a middle-aged man, he demands compensation from the driver for his cleaning expenditures. Later, when he sees his neighbor, the calligrapher, covered in ink stains, he suspects that he has dirtied himself on purpose so that he can claim money from the driver too. He comments that this is a very cunning plan indeed.

After the second manga episode, it became clear that avant-garde calligraphy had been accepted as a familiar cultural phenomenon and feature of the visual and artistic experience of postwar Japan. Inoue Yüichi would later comment that thanks to the two manga episodes and his own photographs in Shükan Asahi, the common people had started associating avant-garde calligraphy with "weird naked old men, smeared in ink and messing with a broom." 26 By this Inoue did not mean to mock the performative aspect of his own work or the popular interest in calligraphy. Rather, he was disappointed that the average viewer noticed only the most superficial aspect of his art and joked about his mode of production. From this point on, Japanese 
calligraphers would have to take into account this common perception of their art.

\section{Art Journals and the Staging of Calligraphy: Georges Mathieu in Japan}

Somewhat more than a year later, in 1957, Japanese audiences demonstrated a similar fascination for the art performed by a foreign abstract painter, perceiving in it an even more staged and provocative performance, without any ironical underpinnings. French abstractionist Georges Mathieu (1921-2012), one of the pioneers of action painting and early performance art, came to Japan in August 1957, at the invitation of the Japanese Gutai group, to introduce his art to the Japanese public. Like his contemporary Pollock, Mathieu focused on the process of creation as his main artistic method and highlighted the importance of speed and subconscious impulse for making his large-scale canvases, some of which were completed within just minutes of a fierce battle with the paint.

Mathieu, "the first Western artist to stage live action paintings as a performance before a viewing public and as a subject of photography," gave a series of performances in several prominent locations in Japan. ${ }^{27}$ In Tokyo, he performed in the atelier garden of the Japanese postwar celebrity artist Okamoto Tarō; in Osaka his painting action took place before a large group of spectators on the roof of Osaka's Daimaru department store. The press covered Mathieu's Japan trip from airstair to airstair, meeting him in Japan at Haneda Airport on August 29, and seeing him off on September 19. ${ }^{28}$ The Yomuiri newspaper, with its strong interest in contemporary art, followed Mathieu's activities particularly closely and even co-sponsored his shows in Tokyo. The same Yomiuri reporters who had introduced Pollock to Japanese audiences and covered Bundō Shunkai's calligraphy performance now focused on the spectacular dynamism and overall 
expression of Mathieu's artistic method; and Mathieu, with his provocative claims and staged public appearances, consciously invited this media attention. In the article dedicated to Mathieu's show in Tokyo, the Yomiuri reporter comments that "Mathieu's artistic manner is truly avantgarde" because of his extravagant self-presentation in "white striped kimono with its sleeves rolled up in traditional way, black obi belt, and red hachimaki band on his forehead," and his unconventional way of "wastefully discarding only half-used paint tubes that each cost three to five thousand yen, and splashing paint on the windows of the brand-new house of Okamoto Tarō, built just three years ago." ${ }^{29}$ The messiness, unconventionality, and sometimes asocial manner of Mathieu fascinated the Yomiuri readership, who ascribed it to his creative fervor and his use of "speed, intuition, and excitement" as a method. ${ }^{30}$ As with Inoue and the calligraphers depicted in the manga, the vanguard atmosphere of his art production captivated the minds of the Japanese viewers. Yet unlike the calligraphers, Mathieu was received with respect and genuine astonishment, rather than irony. From this point on, action painting and performativity became an accepted and established artistic practice in Japan, rather than a curiosity.

The media trend of focusing on art production rather than product continued. Yoshida Toshio, a photographer for the Yomiuri who specialized on arts and culture, took pictures of Mathieu's performances that traveled beyond the Yomiuri and were used, for example, in Geijutsu Shincho, one of Japan's leading art journals. Yoshida captured Mathieu painting, bending, contemplating, and even jumping in front of his canvases. A famous image by Yoshida showed Mathieu's tall figure from the back, caught in a high jump, putting brushstrokes to the canvases covered in black and red lines and circles, in colors that matched his kimono, belt, and headband (plate 10). Reproduced in the Geijutsu Shinchō, this image received a programmatic caption "Action Painting: Mathieu Paints in Japan”. 
Mathieu's activity and public presence in Japan, dubbed the "Mathieu whirlwind" by newspaper reporters, had a direct relation to calligraphy. As Mathieu explained to the Yomiuri readers, "André Malraux called me the first artist in Europe to make calligraphy."31 Comparisons to calligraphy accompanied Mathieu throughout his Japanese sojourn. In the Geijutsu Shinchō article entitled "Confrontation with Calligraphy," Mathieu provocatively claimed that "the fact that I came to Japan means a confrontation between my calligraphy and Japanese calligraphy." ${ }^{232}$ He also criticized modern Japanese calligraphy for not being "free enough," adding that "the task of contemporary Japanese calligraphy and of my own art is the same: we both want to overcome the literary component, and to fulfil the true nature of art. ${ }^{, 33}$ Mathieu further elaborated that the main message of his art was not expressed in words, but lay in the speed of his paintings, because "by painting fast, I am able to capture things that cannot be captured otherwise."34 Mathieu thereby cemented the connection between his action painting-fast, expressive, spectacular, and engaging for the public—and the art of calligraphy. Furthermore, he demonstrated to the Japanese avant-garde calligraphers the possibility of staging their acts of writing in front of audiences, giving it a theoretical motivation.

Mathieu's widespread appeal, and his criticism of contemporary calligraphic practice, was both insulting and stimulating for the avant-garde calligraphers. The situation was further complicated by the fact that Mathieu had come to Japan on the invitation of Yoshihara Jirō, the leader of the Gutai, who had begun making the Gutai group a pioneering force of Japanese contemporary art in direct competition with the calligraphers. Morita Shiryū of the Bokujinkai calligraphy group later complained that they did not have a chance to spend much time with Mathieu, as "it seemed that the Gutai ... wanted to monopolize [Mathieu and art critic Michel Tapié]. "35 Nevertheless, calligraphers were able to meet Mathieu briefly and attend his lecture "Today's World Art and the 
East," organized by Yoshihara in the Asahi Newspaper Building in Osaka. ${ }^{36}$

Mathieu's ideas, public presentation, direct appeal to calligraphy, and artistic method made Japanese calligraphers even more aware of the effect that interaction with the press and mass media could have for their art. Mathieu's success confirmed the benefits of performing calligraphy in front of an audience of viewers, so that not only the calligraphic works, but the calligraphy-making process and the personality of the artist himself could be captured in the flash of the journalists' cameras.

\section{The View from Foreign Journalists: Calligraphy as a New Art}

When Japanese calligraphers reached international audiences by the second half of the 1950s, they were commonly represented abroad in the same way as action painters were in Japan-as avant-garde artist with a strong performative focus, even more so because by this time Japanese calligraphers had begun incorporating performances into their exhibition activity in recognition of action painting. While in the 1950 s only a few calligraphers had paid attention to performativity or had publicized action-oriented photos or videos, by the 1960s performances had become a standard practice of Japanese calligraphers. Foreign photo journalists, followed by Japanese journalists and international artists, perpetuated the image of calligraphy as an East Asian mode of action painting.

Numerous photographs of calligraphic performances appeared in the press during the international tours of Japanese calligraphy artists. One such image shows Morita Shiryū during his performance in German Darmstadt in 1962 (plate 11). Unlike the private setting of photographs of Inoue, Morita is shown making calligraphy in front of viewers, and this publicity 
is obviously an important part of the event. Featured in the German local newspaper Darmstädter Tagblatt, and later reprinted in the calligraphic journal Bokubi, the photograph shows Morita stepping on the paper with one barefoot leg, holding the brush in both hands, and concentrating on his work. The photographer appears to have been watching Morita write from behind the artist's back. The article explains that "you make calligraphy by taking a large brush, putting a sheet of paper on the floor, taking off your shoes, focusing, and quickly drawing the brush over the paint and even faster over the paper." ${ }^{37}$ Morita, who had already highlighted the speed of his writing in Alechinsky's film, reconfirmed his artistic method after encountering Mathieu's theories of speed in art. In his international performances the calligrapher demonstrated a concentration bordering on meditation and inviting comparison with Zen contemplative practices, followed by an extremely fast, fiery, and seemingly uncontrolled writing act. To foreign journalists unfamiliar with calligraphy, his artistic method looked like "a pure expression of vitality (power and movement, as has also become dominant in the latest paintings from North America and Europe)."38 By verbalizing calligraphy’s relation to action painting, German journalists supported the calligraphers' efforts at modernization as well as their international ambitions.

\section{Calligraphy as Media Art: Nam June Paik}

The view of calligraphy as an expressive performance practice soon spread outside of calligraphy. Some six months after Morita's demonstration in German Darmstadt, another set of photographic images became formative for the new perception of a link between calligraphy and action painting. 
In September 1962 the famous "Fluxus Festspiele neuster Musik" took place in Wiesbaden—a forty-minute drive from Darmstadt, where Morita had held his show in May of the same year. A central event in the development of postwar performative and experimental art, the festival hosted fourteen avant-garde concerts and art performances by a diverse group of artists and musicians later to become the core of the international Fluxus movement.

One of the participants was Korean-born experimental artist Nam June Paik, who presented his work Zen for the Head (plate 12). Photographed by Hamburg-based amateur photographer Hartmut Rekort, the photograph shows Nam June Paik crawling on the floor on a long sheet of paper, drawing a line with his hair. In the foreground stands a bucket with dark liquid that looks like ink on a black-and-white photograph, but is in fact a mixture of ink and tomato juice; the traces of Paik's hair are still shimmering wet. The performance was filmed and made a brief appearance on the German television channel Hessischer Rundfunk.

As a photographer of this action and a frequent collaborator with Fluxus artists, Rekort created a dramatic picture by adopting a low frontal viewpoint and stepping to the very edge of the paper, much as the Yomiuri photographers did at Bundō's performance in Tokyo. This work by Paik is often interpreted as reenacting LaMonte Young's Composition 1960 No.10, which consisted of an instruction to "draw a straight line and follow it." "39 However, given Paik's connection to East Asian visual culture, his knowledge of contemporary Japanese art, and the ongoing international success of Japanese calligraphers, which had reached Germany the same year, it is hard to overlook in this performance a reference to East Asian calligraphy, be it contemporary avantgarde or legendary wild cursive. Paik's interest in the effect that new media (in particular, film and television) had on viewers' perception of art, and on the interaction between artist and audience, made his references to calligraphy highly innovative. Conscious of the impact of 
photography and film on art production, Paik chose to recreate the legendary performances of the wild cursive calligraphers in a new, highly public experimental art context. This performance of calligraphic art—brought to its most dramatic performative angle by Paik, documented by Hartmut Rekort, and displayed in the context of Fluxus festival—finalized the public perception of calligraphy as a new avant-garde artform with an impressive tradition behind it and new potential for performativity in visual arts on the global scale.

Unlike Bundō's performance in Tokyo, Paik's Zen for the Head consciously targeted audiences of contemporary art rather than those interested in conventional calligraphy. Here there was an ironic reversal. While in 1952 it surprised Bundō Shunkai and his audience to hear that large calligraphic performances resembled action painting, a suggestion that was initially made by journalists, during Paik's 1962 performance it startled audiences to imagine that this newest and most avant-garde art form could be rooted in the legendary art practices of ancient China. The incorporation of media into calligraphy had changed drastically from the 1950 s to '60s, with a shift from the calligrapher's passively revealing his creative activity to media coverage following the agenda set for calligraphy by journalists, to strategizing media coverage from the inception of a calligraphic performance and using it to realize a specific artistic idea. The press and mass media about calligraphy had been transformed from an advertising and promotional device into the art medium itself. Thus, quite apart from the fact that there was a direct exchange of ideas between avant-garde calligraphy and action painting, mass media played a significant role in shaping the public image of these art forms and bringing them into dialogue with each other. The postwar era had created an image of calligraphy as a type of performative media art that calligraphers were at first hesitant to accept, but later readily incorporated into their practice. 
Studies on action painting from a transcultural perspective include, among others, Joan Marter (ed.), Abstract Expressionism: The International Context (New Brunswick: Rutgers Univ. Press, 2007); Kobena Mercer (ed.), Discrepant Abstraction (Cambridge: MIT Press, 2006); Paul Schimmel et al. (ed.), Out of actions: between performance and the object, 1949-1979 (Los Angeles: Museum of Contemporary Art, 1998).

${ }^{2}$ Bert Winther-Tamaki, Art in the Encounter of Nations (Honolulu: University of Hawai'i Press, 2001); Alexandra Munroe, ed. The Third Mind: American Artists Contemplate Asia, 1860 1989 (New York: Guggenheim Museum, 2009).

${ }^{3}$ Georges Mathieu and Imai Toshimitsu 今井俊満, "書道との対決 [Shodō to no taiketsu; Confrontation with Calligraphy]", Geijutsu Shinchō vol. 8, no. 10 (October 1957), 53-65; Lewis Kachur, "The view from the East: the reception of Jackson Pollock among Japanese Gutai artists", in Joan Marter (ed.), Abstract Expressionism: The International Context, 152162.

${ }^{4}$ For interplays between calligraphy's modernization and education system, see Kenji Kajiya, “Modernized Differently: Avant-Garde Calligraphy and Art in Postwar Japan”, M+ Matters | Postwar Abstraction in Japan, South Korea and Taiwan [28 June 2014], online publication by M+ Hong Kong, http://www.mplusmatters.hk/postwar/paper topic2.php?1=en (accessed June 22, 2017). 
5 Inoue Yūichi 井上有一, Eguchi Sōgen 江口草玄, Sekiya Ōtoshi 関谷大年, Nakamura Bokushi 中村木子, and Morita Shiryū 森田子龍, “墨人会結成挨拶 [Bokujinkai kessei aisatsu; Greeting on the Formation of the Bokujinkai Group]", Bokujin no.1 (April 1952), 2-3. (all translations are by the author, unless otherwise indicated)

6 Yomiuri Shimbun, section Izumi, January 6, 1952, morning Tokyo edition, 3.

${ }^{7}$ Lewis Kachur, “The View from the East: The Reception of Jackson Pollock among Japanese Gutai Artists," 152-65; Shin'ichirō Osaki, "Une stratégie de l'action: Gutai, Pollock, Kaprow [A Strategy for an Action: Gutai, Pollock, Kaprow]," in Gutaï (Paris: Editions du Jeu de paume, 1999), 50-67.

8 Study of the impact of photographs and film by Hans Namuth on the perception of Jackson Pollock became a research field of its own, spanning nearly fifty years of scholarship. Some of the studies include, chronologically, Barbara Rose, 'Hans Namuth's Photographs and the Jackson Pollock Myth: Media Impact and the Failure of Criticism', Arts, vol. 53, no. 7 (March 1979), 116-119; Francis V. O'Connor, “Hans Namuth's Photographs of Jackson Pollock as Art Historical Documentation”, Art Journal, vol. 39, No. 1 (Autumn 1979): 48-49; Peter R. Kalb, “Picturing Pollock: Photography's Challenge to the Historiography of Abstract Expressionism", Journal of Art Historiography, No. 7 (December 2012): 1-17; among others.

9 For controversies of early reception of Jackson Pollock in Japan, see Reiko Tomii “Gutai's Phase Zero: Reading Yoshihara Jirō on Pollock against Takiguchi Shūzō”, lecture manuscript presented at symposium "Tilting the World: Histories of Modern and Contemporary Asian Art”, University of Sydney, November 2013. For the relationship between Pollock's works and early action art by the Japanese Gutai group, see Joan Kee, "Situating a Singular Kind of 
‘Action’: Early Gutai Painting, 1954-1957”, Oxford Art Journal, vol. 26, No. 2 (2003): 123140.

${ }^{10}$ Chih-Mai Chen, Chinese Calligraphers and Their Art (Melbourne: Melbourne University Press, 1966), 92. For more on the Chinese calligraphic tradition of wild cursive, see, for example, Adele Schlombs, Huai-Su and the Beginnings of Wild Cursive Script in Chinese Calligraphy (Stuttgart: Steiner, 1998); Peter S. Sturman, "Wine and Cursive: The Limits of Individualism in Northern Sung China," in Cary Y Liu et al. (ed.), Character and Context in Chinese Calligraphy, (Princeton: Art Museum, Princeton University, 1999), 200-232.

${ }^{11}$ For performativity in Japanese calligraphy manifested in Zen manuscripts, see, for example, Charlotte Eubanks, “Performing Mind, Writing Meditation: Dōgen’s Fukanzazengi as Zen Calligraphy", Ars Orientalis, 46 (2016): 173-198.

12 Interview with Bundō Shunkai's grandson Bundō Keishun in July 2016, Tokyo.

13 The articles from Alechinsky's study of Japanese calligraphy include Pierre Alechinsky, “Calligraphie Japonaise,” Quadrum, (May 1956): 43-53; Pierre Alechinsky, “Japanese Calligraphy and Abstraction,” Graphis 12 (December 1956): 542-55; and Pierre Alechinsky, “ 日本の書道 [Nihon no shodō; Japanese Calligraphy]," Geijutsu Shinchō vol. 6, no. 12

(December 1955): 170-173, among others. The digital version of Alechinsky's original 1956 film is available through the CINEMATEK - Royal Belgian Film Archive, in the "Art \& Cinema (Belgian Art Documentaries)" collection from 2013, edited by Steven Jacobs.

${ }^{14}$ Minute 0:42-0:59 in the film by Pierre Alechinsky, Calligraphie Japonaise, 1956, in Steven Jacobs, ed., “Art \& Cinema (Belgian Art Documentaries)”, 2013.

15 Ibid., min. 02:07-02:18.

${ }^{16}$ Ibid., min. 02:30-03:20. 
17 Ibid., min. 04:05-04:09.

18 Ibid., min. 10:40-10:45.

${ }^{19}$ Suda Kokuta 須田剋太, Nakamura Makoto 中村真, Yoshihara Jirō 吉原治良, Ōsawa Gakyū 大 沢雅休, Morita Shiryū 森田子龍, and Arita Kōhō 有田光浦, “書と抽象絵画・座談会 [Sho to chūshō kaiga: zadankai; Calligraphy and Abstract Painting: A Roundtable Discussion]”, Bokubi no. 26 (August 1953), 11.

20 Minute 12:18-12:55 in Alechinsky, Calligraphie Japonaise, 1956.

21 Ibid., min. 15:01-15:19.

22 For complete collection of the Sazae-san manga series, see Hasegawa Machiko 長谷川町子，サ ザエさん［Sazae-san] (Tokyo: Asashi Shimbunsha, 1997-1998), 23 vol; for English translation, see Hasegawa Machiko, The Wonderful World of Sazae-San, transl. Jules Young and Dominic Young (Tokyo: Kodansha International, 2003), 12 vol.

23 Unagami Masaomi 海上雅臣, 井上有一・書は万人の芸術である[Inoue Yüichi: Sho wa bannin no geijtsu de aru; Inoue Yūichi: Calligraphy is Art for Ten Thousand People], 2nd ed. (Kyoto: Mineruva shobō, 2009), 132. For the information on the 1955 traveling exhibition in Europe, see special issue of the Bokubi journal, 現代日本の書・墨の芸術 [Gendai Nihon no sho: Sumi no geijutsu; Contemporary Japanese Calligraphy: Art of Ink], no. 48 (October 1955).

24 For discussion of new meaning and manifestation of ink in postwar Japanese art, see Bert Winther-Tamaki, "Remediated Ink: The Debt of Modern and Contemporary Asian Ink Aesthetics to Non-Ink Media,” Getty Research Journal, no. 10, January 2018.

25 Unagami，井上有一・書は万人の芸術である [Inoue Yūichi: Calligraphy Is Art for Ten Thousand People], 132. 
26 Ibid., 133.

27 Tracey Warr, The Artist's Body (London: Phaidon, 2000), 50.

28 “仏の異色画家来日一東京で個展開くマチウ氏 [Furansu no ishoku gaka rainichi: Tōkyō de koten hiraku Machiu shi; French Eccentric Artist Arrives to Japan: Mathieu Opens His Solo Exhibition in Tokyo],” Yomiuri Shimbun, August 30, 1957, morning edition, 7; “フランシス氏 来日ーマチウ氏はゆうべアメリカへ[Furanshisu shi rainichi-Machiu shi wa yūbe Amerika e; Francis Arrives to Japan, and Mathieu Leaves Tonight for America],” Yomiuri Shimbun, September 20, 1957, morning edition, 7. 29 “スピード、直感、興奮 [Spīdo, chokkan, kofun; Speed, Intuition, Excitement],” Yomiuri Shimbun, September 1, 1957, morning edition, 5.

30 Ibid

31 “仏の異色画家来日一東京で個展開くマチウ氏 [French Eccentric Artist Arrives to Japan: Mathieu Opens His Solo Exhibition in Tokyo]," Yomiuri Shimbun, 7.

32 Mathieu and Imai, “書道との対決 [Confrontation with Calligraphy],” 57.

33 Ibid., 62.

34 Ibid., 60.

35 Interview with Morita Shiryū by art critic Takemoto Tadao at Morita's home in Kyoto in 1972, published in Chisaburo Yamada, Dialogue in Art: Japan and the West (Tokyo; New York:

Kodansha International Ltd., 1976), 307.

${ }^{36}$ Gutai's Chronology compiled by Hirai Shōichi, in Ming Tiampo and Alexandra Munroe, ed. Gutai-Splendid Playground (New York: Guggenheim Museum Publ., 2013), 288.

37 Darmstädter Tagblatt from May 7, 1962, reprinted in Bokubi no. 121, special issue ドイッ巡 
回日本書展 [Doitsu junkai Nihon shoten; Traveling Exhibition in Germany], (October 1962), p.

23.

38 'Vertrautes in fremder Kunst - Japanische Gäste zeigen das Werden der Kalligraphie [The Familiar in Foreign Art_-Japanese Guests Show the Creation of Calligraphy]', Darmstädter Echo (Darmstadt, May 5, 1962), n.p.

39 As, for example, in Alexandra Munroe, "Buddhism and the Neo-Avant-Garde: Cage Zen, Beat Zen, and Zen," in Alexandra Munroe, ed. The Third Mind: American Artists Contemplate Asia, 1860-1989, 203. 


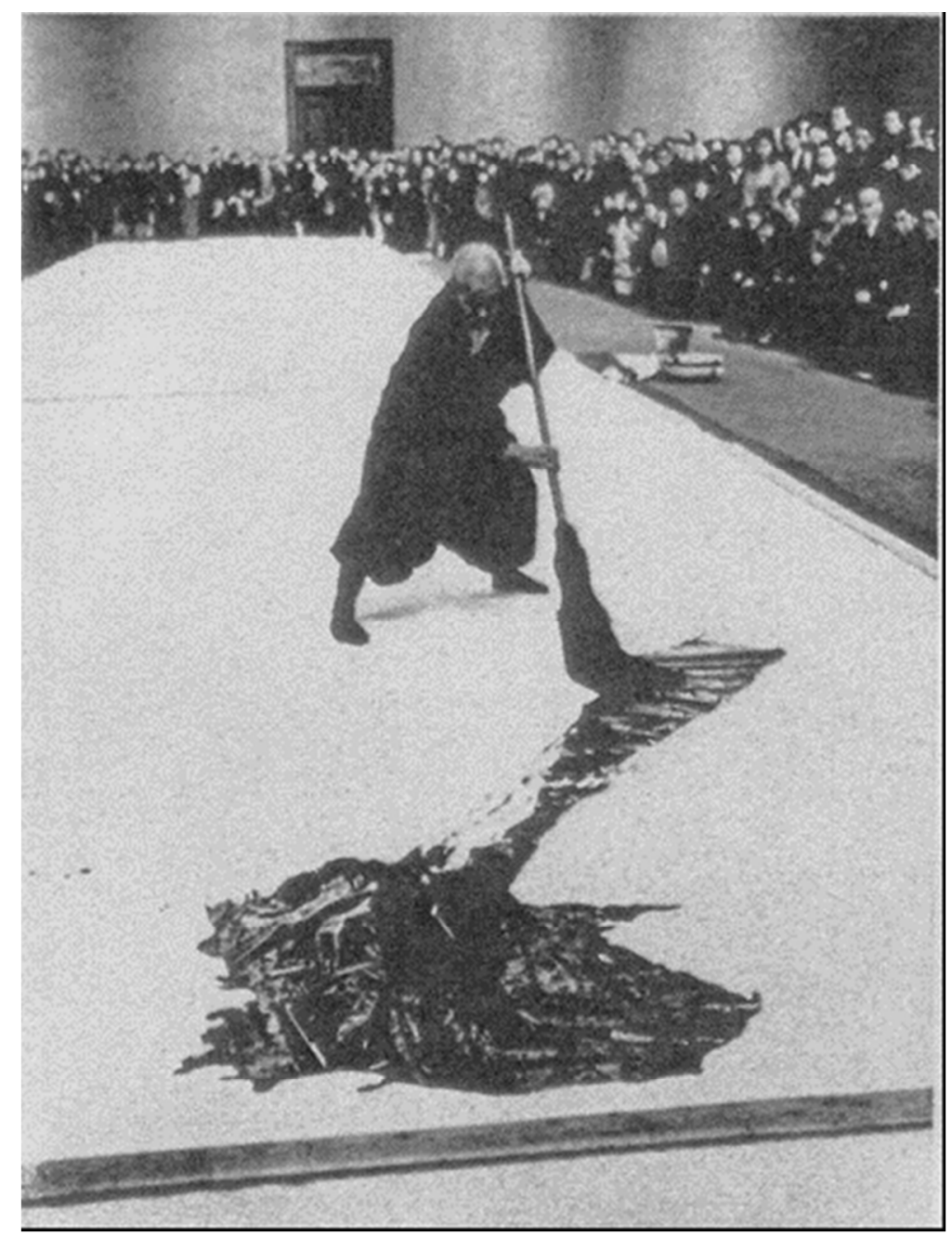

Plate 1. Bundō Shunkai during his calligraphy performance at Tokyo Metropolitan Art Museum, January 5, 1952. Photograph provided by Bundō Keishun. 


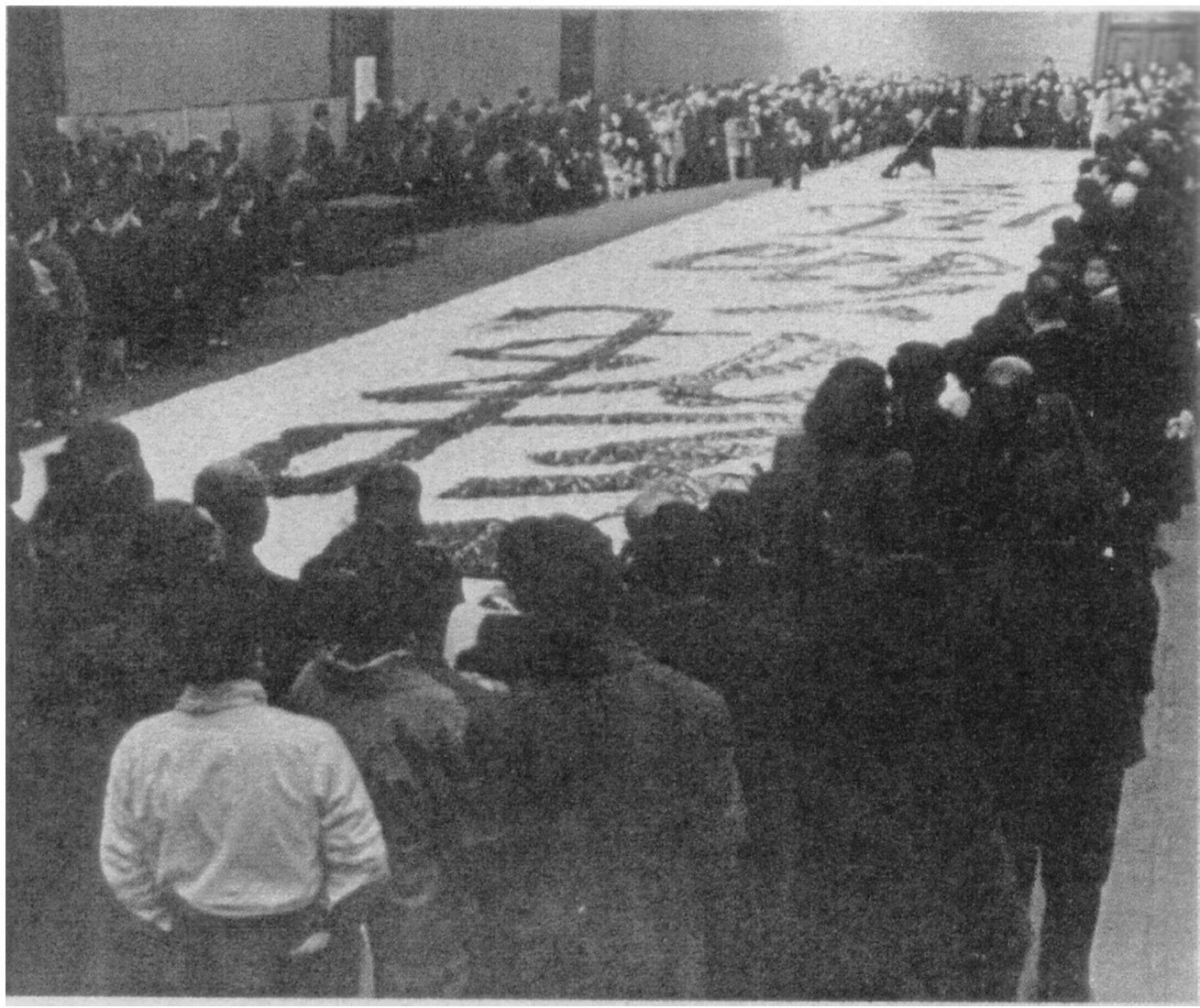

Plate 2. Bundō Shunkai during his calligraphy performance at Tokyo Metropolitan Art Museum, January 5, 1952. Photograph provided by Bundō Keishun.

$113 \times 95 \mathrm{~mm}(220 \times 220 \mathrm{DPI})$ 


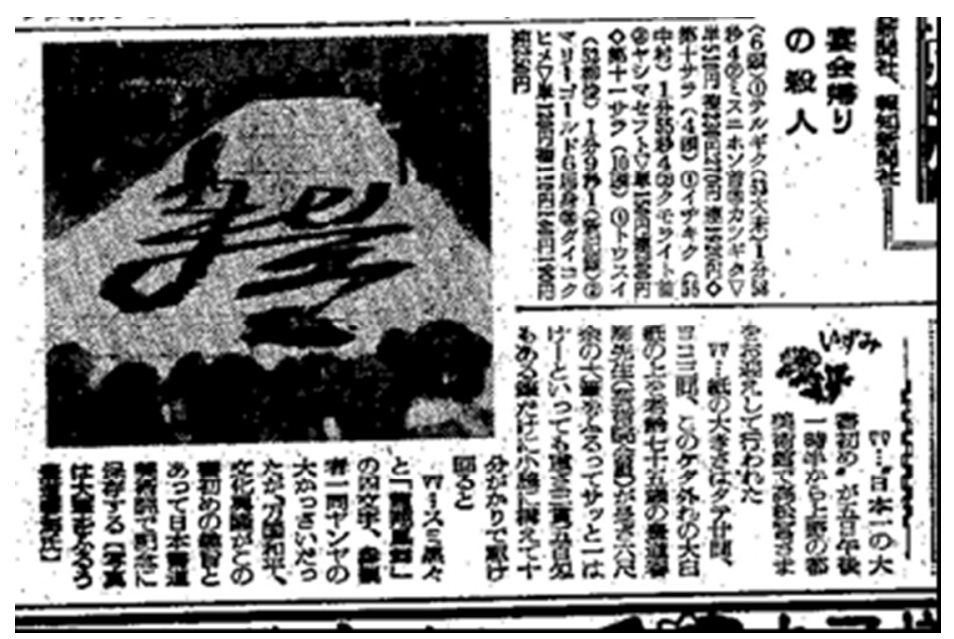

Plate 3. Note in Yomiuri Shimbun newspaper featuring a photograph of Bundō Shunkai's calligraphy performance at Tokyo Metropolitan Art Museum. Yomiuri Shimbun, January 6, 1952, morning Tokyo edition, 3. 
Plate 4. School children repeating teacher's movement when learning characters, minute 02:52 in film by Pierre Alechinsky Calligraphie Japonaise, 1956, available through CINEMATEK - Royal Belgian Film Archive, Steven Jacobs, ed., "Art \& Cinema (Belgian Art Documentaries)", 2013. 


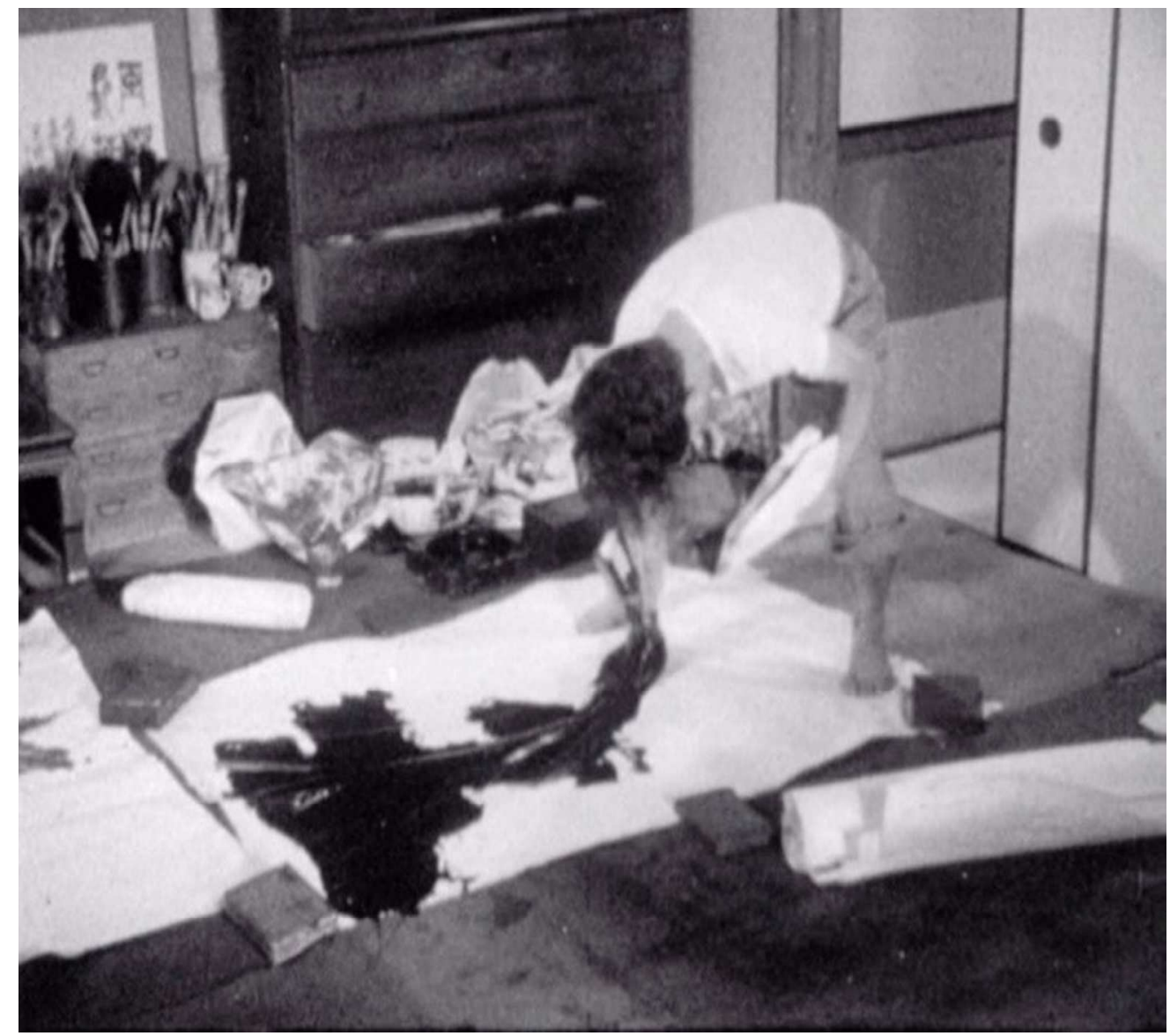

Plate 5. Morita Shiryū writing calligraphy in his atelier, minute 12:57 in Pierre Alechinsky's film Calligraphie Japonaise, 1956.

$88 \times 78 m m(220 \times 220$ DPI $)$ 
Plate 6. Episode "Avant-garde Calligraphy" of the newspaper manga series Sazae-san by Hasegawa Machiko, published in Asahi Shimbun on January 31, 1956, Tokyo edition, 9. 


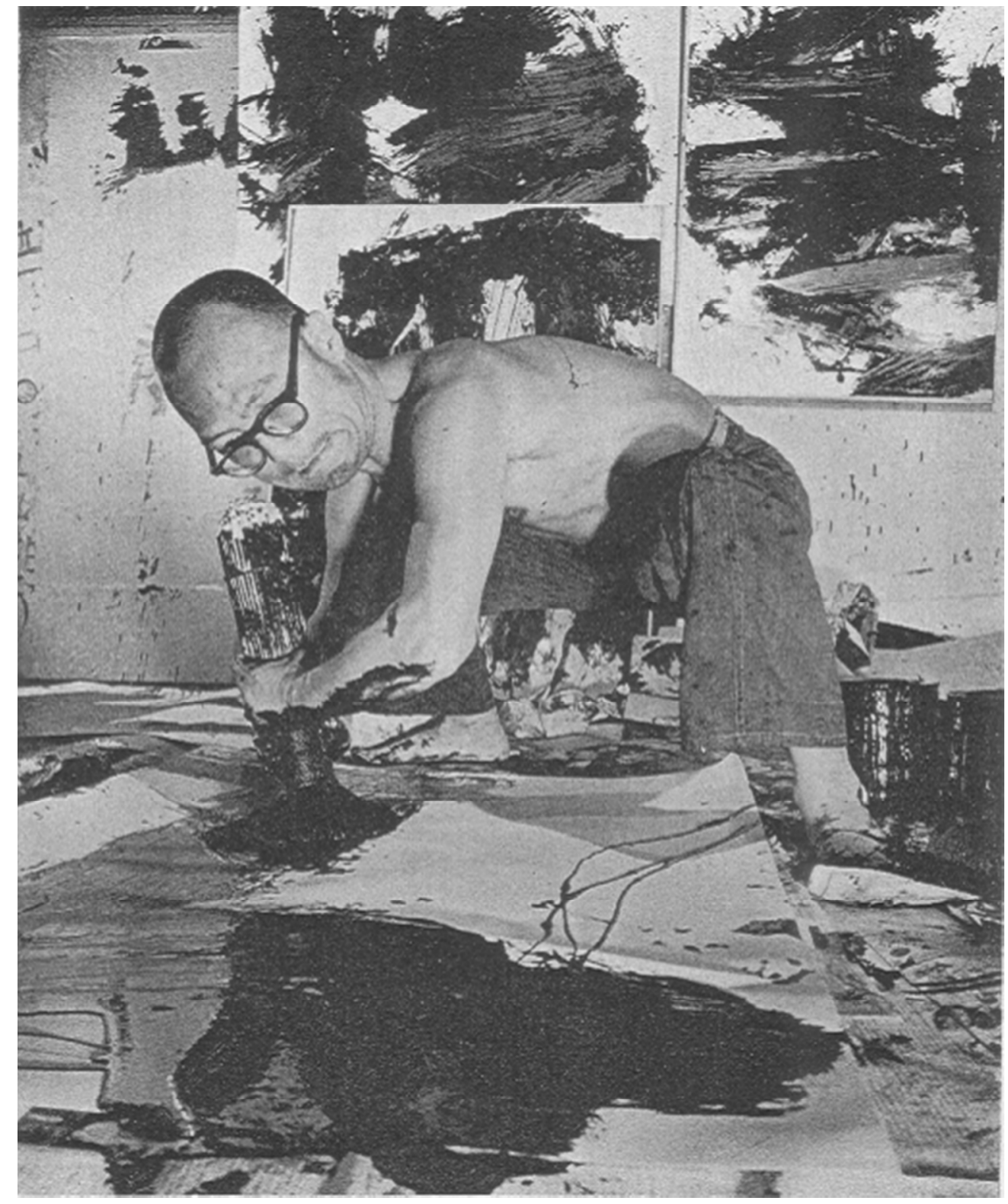

Plate 7. Inoue writing abstract calligraphy in his home atelier for the traveling exhibition in Europe, 1955. Photograph by Sugano Yoshikatsu. Photograph featured on the cover of the Shūkan Asahi journal dedicated to avant-garde calligraphy, from February 5, 1956, and reprinted in Bokubi journal no.64 (March 1957). Photograph provided by UNAC Tokyo. 


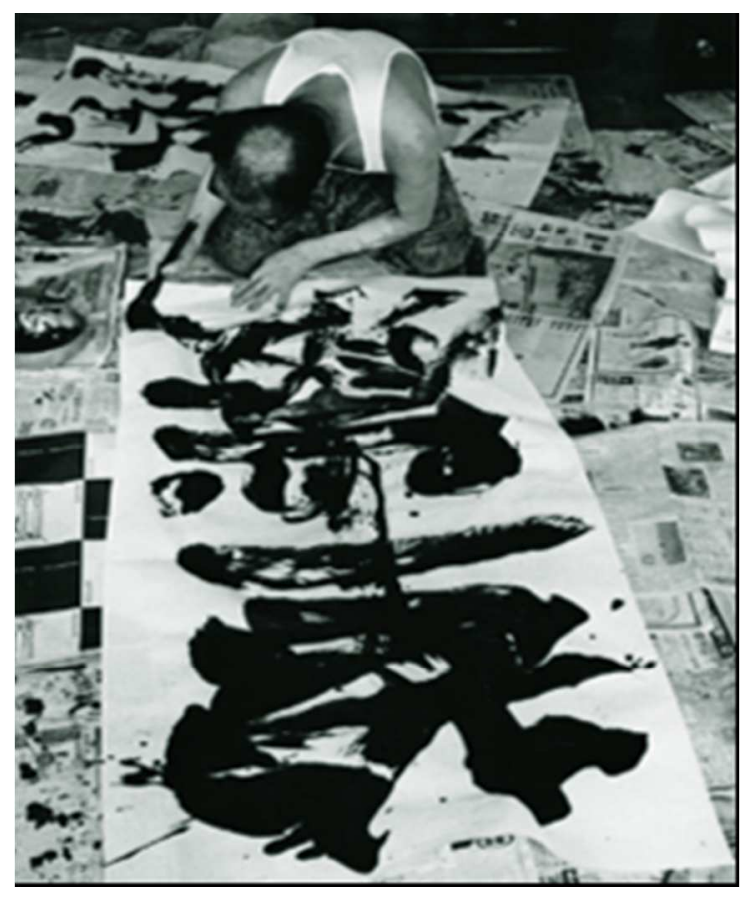

Plate 8. Avant-garde print artist Munakata Shikō (1903-1975) making calligraphy in his atelier, 1967. Photograph by Domon Ken for the "Tales of Masters of Japan" series. Photograph provided by Domon Ken Memorial Museum. 


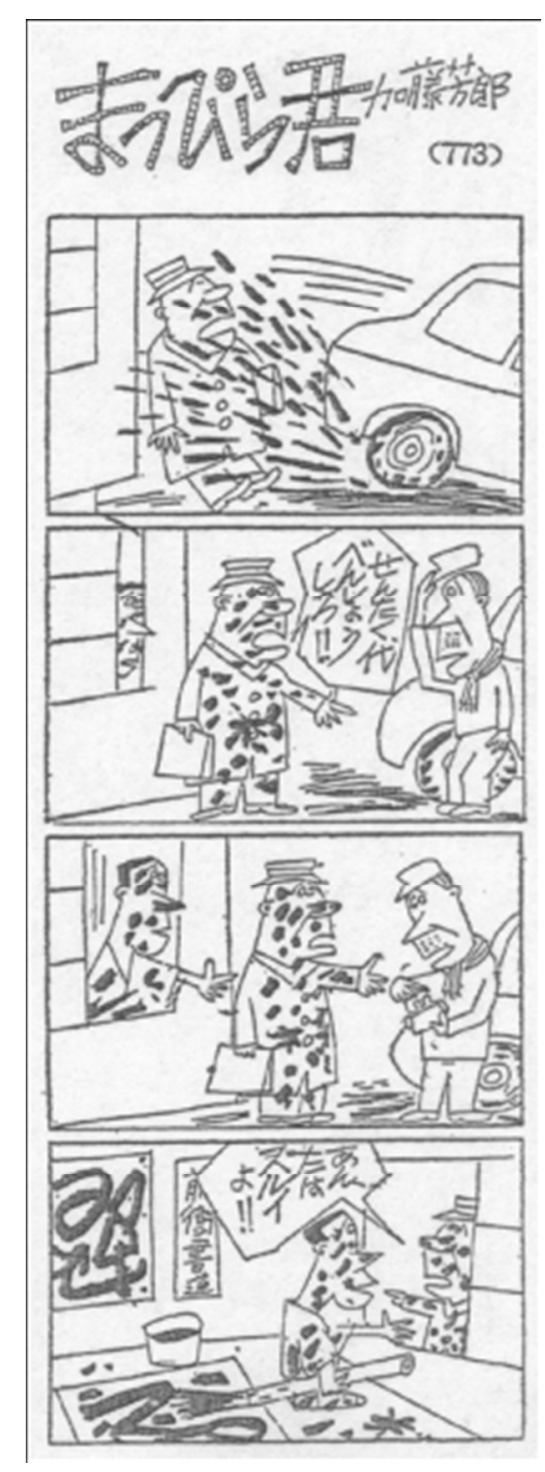

Plate 9. Episode no. 773 of the newspaper manga series Mappira-kun by Katō Yoshirō, published in Mainichi Shimbun, March 2, 1956, Tokyo evening edition, p. 7. 
Plate 10. Georges Mathieu during his action painting demonstration in Tokyo in September 1957.

Photograph by Yoshida Toshio. Caption reads: "Action Painting: Georgea Mathieu Paints in Japan". Photograph from the special issue of the art journal Geijutsu Shinchō, 8 (October 1957), 53, originally published in the Yomiuri Shimbun newspaper article "スピード、直感、興奮 [Speed, Intuition, Excitement]," from September 1, 1957, morning Tokyo edition, 5. 
Plate 11. Photograph of Morita Shiryū's avant-garde calligraphy demonstration in German Darmstadt in 1962, published in Darmstädter Tagblatt on May 7, 1962, and reprinted in the journal Bokubi, no. 121, special issue ドイツ巡回日本書展 [Traveling Exhibition of Japanese Calligraphy in Germany], (October 1962), 23. 


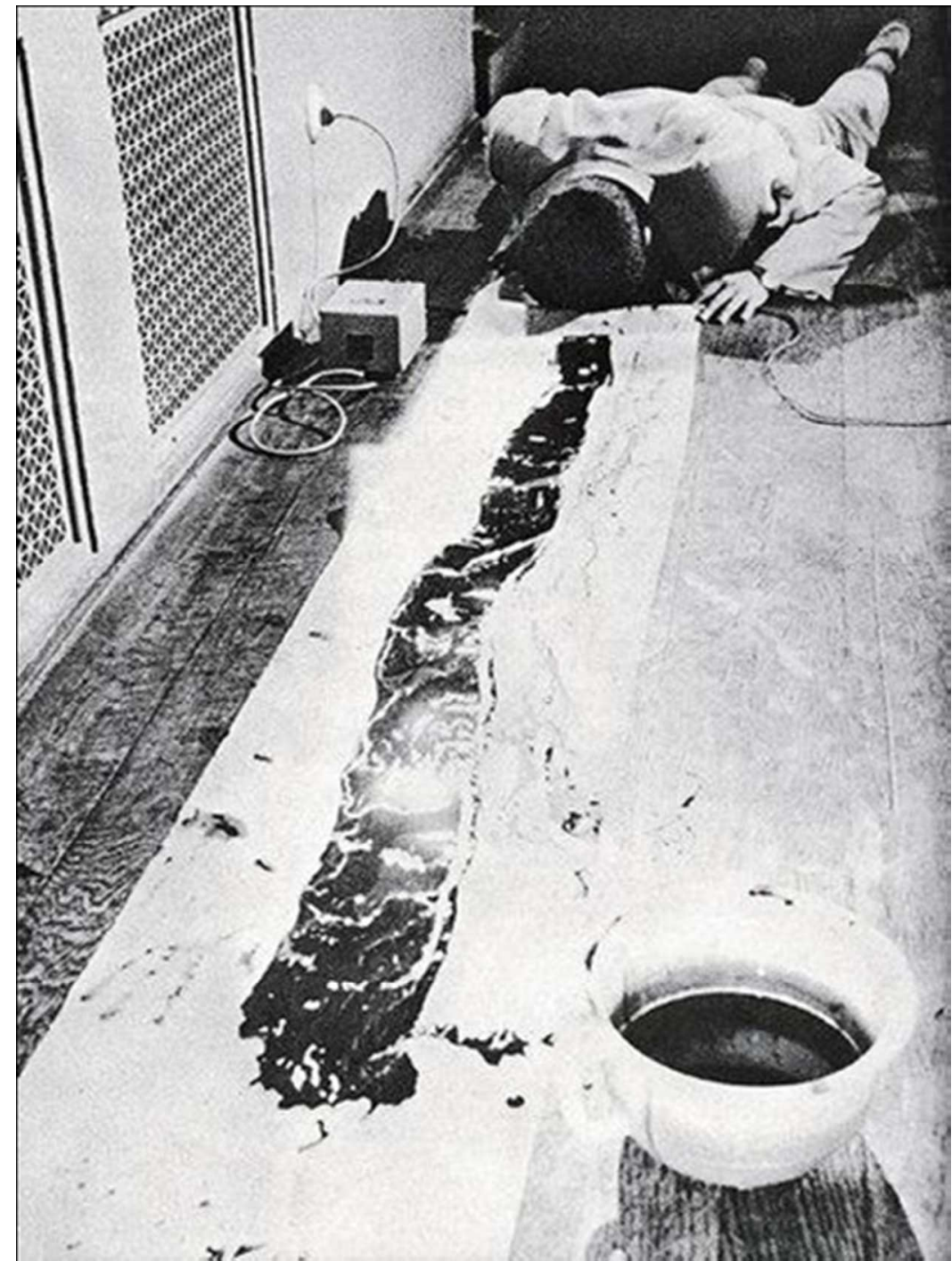

Plate 12. Nam June Paik performing Zen for the Head at Fluxus Festspiele neuester Musik in German Wiesbaden in September 1962. Photograph by Hartmut Rekort. 


\section{References}

Alechinsky, Pierre. Calligraphie Japonaise, film, 1956. In CINEMATEK - Royal Belgian Film Archive, in Steven Jacobs (ed.), Art \& Cinema (Belgian Art Documentaries), 2013.

Alechinsky, Pierre, “Calligraphie Japonaise.” Quadrum, May 1956, 43-53.

Alechinsky, Pierre. “Japanese Calligraphy and Abstraction.” Graphis 12, December 1956, 542-55.

Alechinsky, Pierre. “日本の書道 [Nihon no shodō; Japanese Calligraphy].” Geijutsu Shinchō vol. 6, no. 12, December 1955, 170-173.

Barnes, Laurie. “Spirit, Brush, and Ink: Dong Qichang's Tribute to the Wild Cursive Calligraphy of Zhang Xu." Bulletin of the Detroit Institute of Arts/ Publ. by the Founders Society, Detroit Institute of Arts, 2008, 46-59.

Chen, Chih-Mai. Chinese Calligraphers and Their Art. Melbourne: Melbourne University Press, 1966.

Eubanks, Charlotte. "Performing Mind, Writing Meditation: Dōgen's Fukanzazengi as Zen Calligraphy." Ars Orientalis vol. 46, 2016, 173-198.

“Furansu no ishoku gaka rainichi--Tōkyō de koten hiraku Machiu sh;i 仏の異色画家来日一東京で個展開 くマチウ氏 [French Eccentric Artist Arrives to Japan: Mathieu Opens His Solo Exhibition in Tokyo]." Yomiuri Shimbun, August 30, 1957, morning edition, 7.

"Furanshisu shi rainichi-Machiu shi wa yūbe Amerika e; フランシス氏来日ーマチウ氏はゆうベアメリ

カヘ [Francis Arrives to Japan, and Mathieu Leaves Tonight for America].” Yomiuri Shimbun, September 20, 1957, morning edition, 7.

Hasegawa Machiko 長谷川町子. The Wonderful World of Sazae-San. Translated by Jules Young and Dominic Young. Tokyo: Kodansha International, 2003.

Hasegawa Machiko 長谷川町子.サザエさん [Sazae-san]. 23 vol. Tokyo: Asahi Shimbunsha, 1997.

Inoue Yūichi 井上有一, Eguchi Sōgen 江口草玄, Sekiya Ōtoshi 関谷大年, Nakamura Bokushi 中村木子, and Morita Shiryū 森田子龍, “Bokujinkai kessei aisatsu 墨人会結成挨拶 [Greeting on the Formation of the Bokujinkai Group].” Bokujin no.1, April 1952, 2-3. 
Kachur, Lewis. "The View from the East: The Reception of Jackson Pollock among Japanese Gutai Artists." In Abstract Expressionism: The International Context, ed. by Joan M. Marter, 152-65. New Brunswick, N.J: Rutgers University Press, 2007.

Kalb, Peter. "Picturing Pollock: Photography's Challenge to the Historiography of Abstract Expressionism." Journal of Art Historiography, No. 7, December 2012, 1-17.

Kee, Joan. "Situating a Singular Kind of ‘Action': Early Gutai Painting, 1954-1957.” Oxford Art Journal, vol. 26, No. 2, 2003, 123-140.

Kenji Kajiya. "Modernized Differently: Avant-Garde Calligraphy and Art in Postwar Japan”, M+ Matters | Postwar Abstraction in Japan, South Korea and Taiwan [28 June 2014], online publication by M+ Hong Kong, http://www.mplusmatters.hk/postwar/paper_topic2.php?1=en (accessed June 22, 2017).

Marter, Joan, ed. Abstract Expressionism: The International Context. New Brunswick: Rutgers Univ. Press, 2007.

Mercer, Kobena, ed. Discrepant Abstraction. London: Institute of International Visual Arts; Cambridge: MIT Press, 2006.

Ming Tiampo and Alexandra Munroe, ed. Gutai--Splendid Playground. New York: Guggenheim Museum, 2013.

Munroe, Alexandra, ed. The Third Mind: American Artists Contemplate Asia, 1860 - 1989. New York: Guggenheim Museum, 2009.

Munroe, Alexandra. "Buddhism and the Neo-Avant-Garde: Cage Zen, Beat Zen, and Zen." In The Third Mind: American Artists Contemplate Asia, 1860-1989, by Alexandra Munroe, 199-216. New York: Solomon R. Guggenheim Museum, 2009.

Francis V. O'Connor, "Hans Namuth's Photographs of Jackson Pollock as Art Historical Documentation”, Art Journal, vol. 39, No. 1, Autumn 1979, 48-49.

Osaki, Shin'ichirō. "Une stratégie de l'action: Gutai, Pollock, Kaprow.” In Gutaï, edited by Galerie nationale du Jeu de Paume, 50-67. Paris: Editions du Jeu de paume, 1999. 
Suda Kokuta 須田勊太, Nakamura Makoto 中村真, Yoshihara Jirō 吉原治良, Ōsawa Gakyū 大沢雅休, Morita Shiryū 森田子龍, and Arita Kōhō 有田光浦, “書と抽象絵画・座談会 [Sho to chūshō kaiga: zadankai; Calligraphy and Abstract Painting: A Roundtable Discussion].” Bokubi no. 26, August 1953, 11.

Tomii, Reiko. "Gutai’s Phase Zero: Reading Yoshihara Jirō on Pollock against Takiguchi Shūzō”, unpublished lecture manuscript presented at symposium "Tilting the World: Histories of Modern and Contemporary Asian Art”, University of Sydney, November 2013.

Unagami Masaomi 海上雅臣. 井上有一・書は万人の芸術である [Inoue Yüichi: Sho wa bannin no geijtsu de aru; Inoue Yūichi: Calligraphy is Art for Ten Thousand People], 2nd ed. Kyoto: Mineruva shobō, 2009.

'Vertrautes in fremder Kunst - Japanische Gäste zeigen das Werden der Kalligraphie [The Familiar in Foreign Art—Japanese Guests Show the Creation of Calligraphy]', Darmstädter Echo. May 5, 1962, n.p.

Warr, Tracey. The Artist's Body. London: Phaidon, 2000. 
Winther-Tamaki, Bert. Art in the Encounter of Nations. Honolulu: University of Hawai'i Press, 2001.

Winther-Tamaki, Bert. "The Asian Dimensions of Postwar Abstract Art: Calligraphy and Metaphysics.”

In The Third Mind: American Artists Contemplate Asia, 1860-1989, by Alexandra Munroe, 145-

57. New York: Solomon R. Guggenheim Museum, 2009.

Winther-Tamaki, Bert. "Remediated Ink: The Debt of Modern and Contemporary Asian Ink Aesthetics to Non-Ink Media." Getty Research Journal, no. 10, January 2018.

Yamada, Chisaburo. Dialogue in Art: Japan and the West. Tokyo and New York: Kodansha International, 1976.

Mathieu, Georges and Imai Imai Toshimitsu 今井俊満. “書道との対決 [Shodō to no taiketsu; Confrontation with Calligraphy]." Geijutsu Shinchō vol. 8, no. 10 (October 1957): 53-65. 